University of Nebraska - Lincoln

DigitalCommons@University of Nebraska - Lincoln

\title{
Evidence for the Timing and Duration of the Last Interglacial Period from High-Precision Uranium-Series Ages of Corals on Tectonically Stable Coastlines
}

Daniel R. Muhs

U.S. Geological Survey, dmuhs@usgs.gov

Follow this and additional works at: https://digitalcommons.unl.edu/usgsstaffpub

Part of the Earth Sciences Commons

Muhs, Daniel R., "Evidence for the Timing and Duration of the Last Interglacial Period from High-Precision Uranium-Series Ages of Corals on Tectonically Stable Coastlines" (2002). USGS Staff -- Published Research. 173.

https://digitalcommons.unl.edu/usgsstaffpub/173

This Article is brought to you for free and open access by the US Geological Survey at DigitalCommons@University of Nebraska - Lincoln. It has been accepted for inclusion in USGS Staff -- Published Research by an authorized administrator of DigitalCommons@University of Nebraska - Lincoln. 


\title{
Evidence for the Timing and Duration of the Last Interglacial Period from High-Precision Uranium-Series Ages of Corals on Tectonically Stable Coastlines
}

\author{
Daniel R. Muhs ${ }^{1}$ \\ U.S. Geological Survey, MS 980, Box 25046, Federal Center, Denver, Colorado 80225
}

Received September 6, 2001

\begin{abstract}
The last interglacial period has a timing and duration that can be estimated from U-series dating of emergent, coral-bearing deposits on tectonically stable coastlines. High-precision dating from Bermuda, the Bahamas, Hawaii, and Australia suggests that the last interglacial period had a sea level at least as high as present from $\sim 128,000$ to 116,000 yr B.P. Sea level reached a near-present level more quickly after the close of the penultimate glacial period than at the close of the last glacial period and the duration of high sea level is longer than that implied by the deep-sea record. (c) 2002 University of Washington.
\end{abstract}

Key Words: last interglacial; sea level; U-series dating; corals.

The timing and climate variability of the last interglacial period are topics that have been actively debated (Kukla, 2000). The oxygen isotope record of foraminifera in deep-sea cores suggests that the peak of the last interglacial period (substage $5 \mathrm{e}$ or 5.5) began around $128,000 \mathrm{yr}$ and lasted for perhaps no more than 12,000 yr (Martinson et al., 1987). The period over which global ice volume was similar to, or less than, present is estimated to be considerably shorter, however. For example, in a high-resolution core from Santa Barbara Basin, California, oxygen-isotope values lighter than those of the past $5000 \mathrm{yr}$ (when sea level had reached its present elevation) are recorded in benthic foraminifera during a period estimated to occur only from $\sim 125,000$ to $118,000 \mathrm{yr}$ B.P. (Kennett, 1995).

Global ice volumes vary inversely with sea level. High sea levels during interglacial periods leave abandoned terraces and reefs both on tectonically stable and rising coastlines. On stable coastlines, a simple model would suggest that marine terraces or reefs will be left as emergent records only during times that sea level is higher-and therefore global ice volume is lowerthan present. This concept is complicated, however, by glaciohydro-isostatic contributions to sea level, i.e., deformation of the Earth's surface associated with the growth and decay of large ice sheets (Lambeck and Chappell, 2001). Thus, it is possible that coastlines closer to Northern Hemisphere ice sheets will

\footnotetext{
${ }^{1}$ E-mail: dmuhs@usgs.gov.
}

record apparent sea-level histories (for both the magnitude and timing of sea-level rise or fall) that differ from those distant from the ice sheets. Nevertheless, it is interesting to note that in the western Atlantic Ocean, deposits that date to the peak of the last interglacial period, from tectonically stable Bermuda $\left(\sim 32^{\circ} \mathrm{N}\right)$, the Florida Keys $\left(\sim 25^{\circ} \mathrm{N}\right)$, the Bahamas $\left(\sim 24-21^{\circ} \mathrm{N}\right)$, the Yucatan Peninsula $\left(\sim 20^{\circ} \mathrm{N}\right)$, and southern Brazil $\left(\sim 30^{\circ} \mathrm{S}\right)$ all have paleo-sea-level indicators with similar elevations, i.e., about 3-8 m above modern sea level (Szabo et al., 1978; Martin et al., 1988; Chen et al., 1991; Fruijtier et al., 2000; Muhs et al., 2002).

Corals in reefs or other marine deposits can be accurately and precisely dated by U-series methods via thermal ionization mass spectrometry. New instrumental advances in inductively coupled plasma (ICP) mass spectrometry also hold considerable promise for U-series dating (Stirling et al., 2001). Critical to all age interpretations is an absence of evidence for diagenetic processes that would result in open-system conditions with respect to $U$ and its daughter products. Ideally, an analysis would include both ${ }^{230} \mathrm{Th} /{ }^{234} \mathrm{U}$ and ${ }^{231} \mathrm{~Pa} /{ }^{235} \mathrm{U}$ age estimates. Closed-system history is ascertained by concordance between the two isotopic systems (Edwards et al., 1997). At present, however, few laboratories are capable of making high-precision ${ }^{231} \mathrm{~Pa} /{ }^{235} \mathrm{U}$ analyses. Nevertheless, four other factors are also considered for reliability of ages by the ${ }^{230} \mathrm{Th} /{ }^{234} \mathrm{U}$ method. A coral must have (1) the original aragonite mineralogy (U is lost during recrystallization), (2) $\mathrm{U}$ contents that are within the range of living species, (3) low amounts of ${ }^{232} \mathrm{Th}$ (an indicator of detrital contamination), and (4) back-calculated initial ${ }^{234} U /{ }^{238} U$ values that are within the range of seawater and living corals.

In the absence of ${ }^{231} \mathrm{~Pa} /{ }^{235} \mathrm{U}$ analyses, the back-calculated initial ${ }^{234} \mathrm{U} /{ }^{238} \mathrm{U}$ value is the most important criterion for verification of a closed-system isotopic history. In laboratories at the U.S. Geological Survey, measurement of ${ }^{234} U /^{238} U$ values in living or modern-dead corals from the Bahamas, Florida, Bermuda, and California give a range of 1.142 to 1.151 , with a mean of $1.147(n=20)$. Stirling et al. (1995) report values of 1.148 1.149 for living corals $(n=3)$. All these data are in agreement with the range of ${ }^{234} \mathrm{U} /{ }^{238} \mathrm{U}$ measurements of modern seawater (Chen et al.,1986).Using both theoretical concepts and empirical 


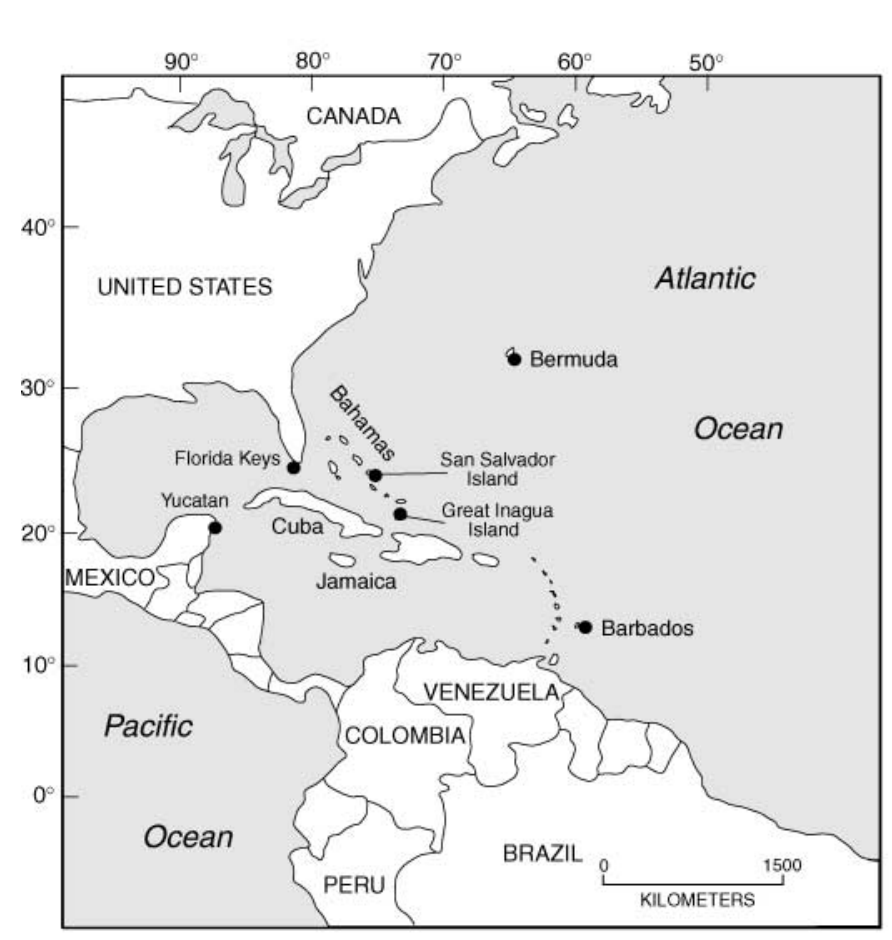

(a)

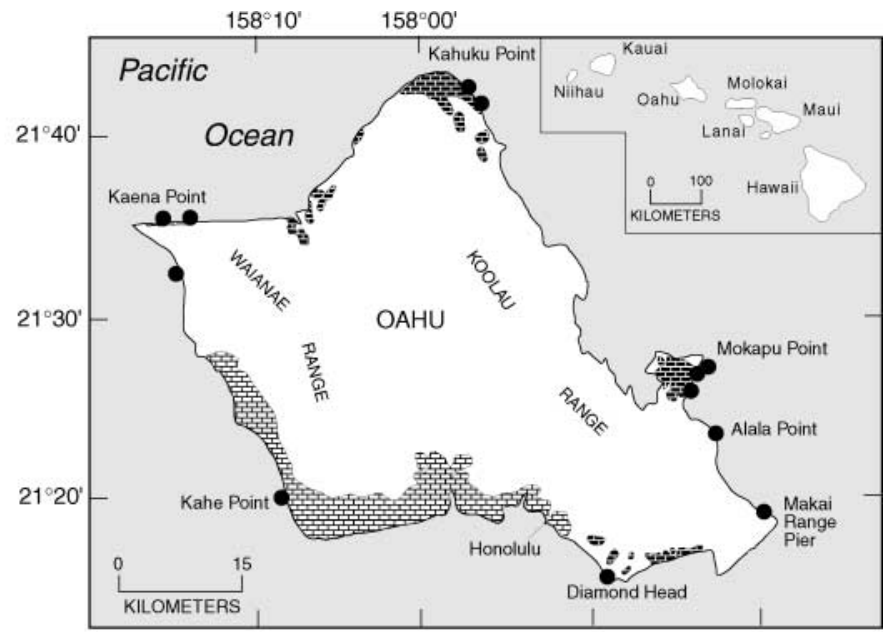

(b)

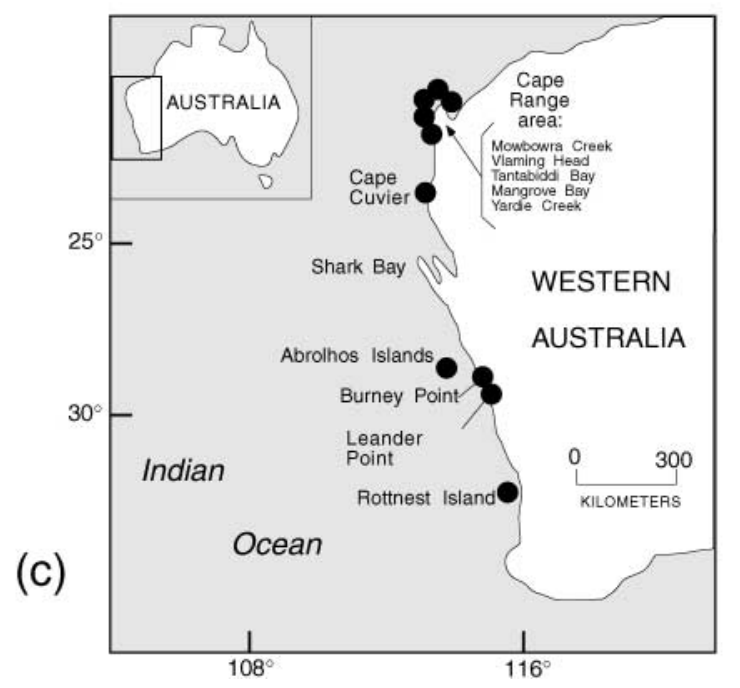

FIG. 1. Maps showing locations of high-precision U-series ages of corals and localities referred to in the text: (a) the western Atlantic region with Bermuda and the Bahamas; (b) Oahu, Hawaii (patterned areas are emergent reef limestones from compilation by Muhs and Szabo, 1994); (c) Western Australia.

data from Barbados corals, Gallup et al. (1994) estimate that higher than modern back-calculated initial ${ }^{234} \mathrm{U} /{ }^{238} \mathrm{U}$ values bias calculated U-series ages to older estimates. They suggest, for example, that if a coral hypothetically began with an initial ${ }^{234} \mathrm{U} /{ }^{238} \mathrm{U}$ value of 1.149 but ultimately has a back-calculated initial ${ }^{234} \mathrm{U} /{ }^{238} \mathrm{U}$ value of 1.153 , it has experienced open-system conditions and may be biased old by about 1000 yr. Analytical uncertainties (2 sigma) are also typically about $1000 \mathrm{yr}$ for corals of last-interglacial age. Thus, if the model of Gallup et al. (1994) is correct, then "acceptable" back-calculated initial ${ }^{234} \mathrm{U} /{ }^{238} \mathrm{U}$ values could be considered to be those samples with values of $1.149 \pm 0.004$. In this review, only data for corals that are free of recrystallization, have acceptable U contents, and have low ${ }^{232} \mathrm{Th}$ contents are presented. Within this pool of samples, interpretations about the timing and duration of the last interglacial period are made only from those corals whose back-calculated initial ${ }^{234} \mathrm{U} /{ }^{238} \mathrm{U}$ values are within the range of $1.149 \pm 0.004$, the same criterion used by Stirling et al. (1995, 1998). All age uncertainties reported here are 2 sigma.

Sea-level records on tectonically stable islands (Bermuda, Florida Keys, and the Bahamas) of the western Atlantic Ocean (Fig. 1a) consist of emergent reefs and coral-bearing shallow marine and beach deposits. On Bermuda, corals are found in emergent $(+2-3 \mathrm{~m})$ marine deposits that have acceptable ages ranging (using the criteria described above) from $118,900 \pm 600$ to $113,400 \pm 900$ yr B.P. (Muhs et al., 2002). The Key Largo Limestone of the Florida Keys contains abundant corals, but preservation is generally poor. Even all unrecrystallized Key Largo corals recently analyzed, though apparently of last-interglacial age, show an open-system history (Fruijtier et al., 2000). In contrast, fossil reefs in the Bahamas are generally well preserved (Chen et al., 1991). Reefs have elevations up to $5 \mathrm{~m}$ above sea level and many are in growth position. On San Salvador and Great 
(a)

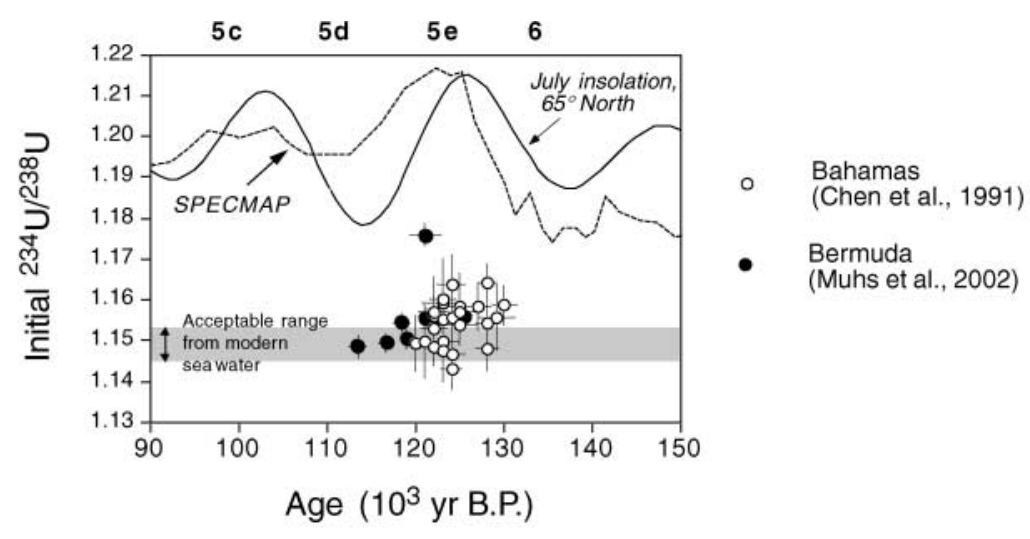

(b)

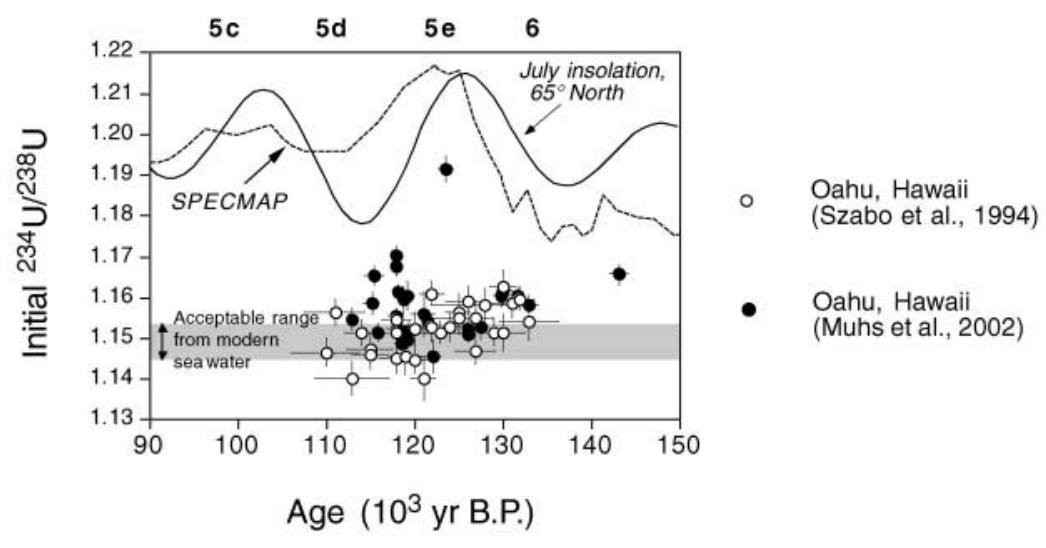

(c)

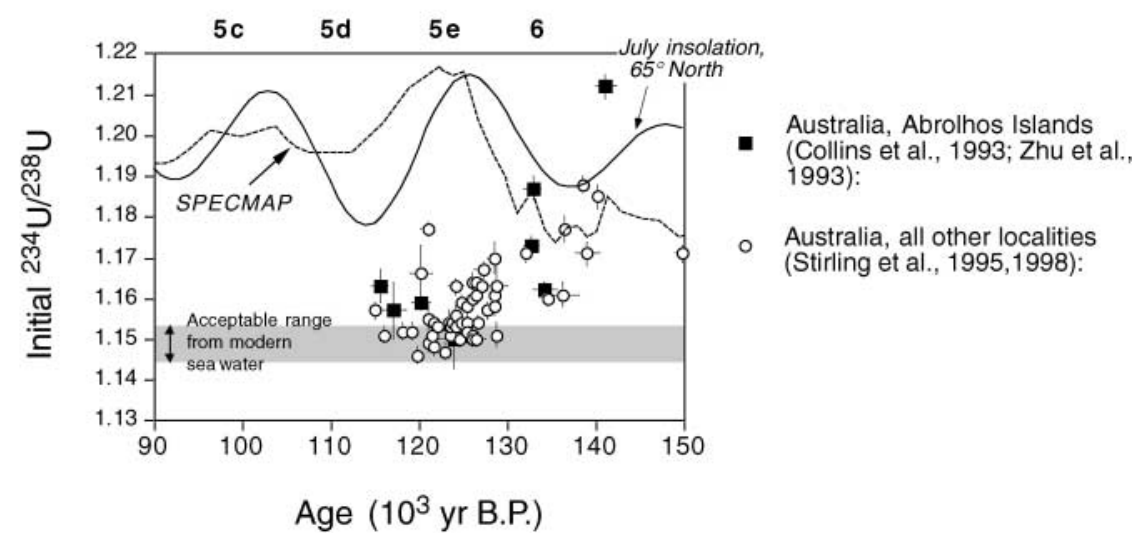

FIG. 2. U-series ages plotted against their calculated initial ${ }^{234} U / 238 U$ activity values. Error bars are 2 sigma; where not shown, errors are less than the symbol size. Shaded box shows range of back-calculated initial ${ }^{234} \mathrm{U} /{ }^{238} \mathrm{U}$ activity values that are thought to indicate samples with closed-system histories. Shown for comparison are July insolation (in $\mathrm{W} / \mathrm{m}^{2}$ ) at the top of the atmosphere at $65^{\circ} \mathrm{N}$ (Berger and Loutre, 1991) and the normalized SPECMAP oxygen isotope curve (Martinson et al., 1987). Bold numbers at top are oxygen isotope stages and substages. (a) Bahamas and Bermuda (Chen et al., 1991; Muhs et al., 2002). (b) Hawaiian Islands (Szabo et al., 1994; Muhs et al., 2000). (c) Western Australia (Stirling et al., 1995, 1998; Zhu et al., 1993).

Inagua Islands, acceptable ages range from $127,900 \pm 1200$ to $119,900 \pm 1400$ yr B.P. (Fig. 2a).

The last interglacial period on Oahu, in the Hawaiian Islands (Fig. 1b), is recorded by the Waimanalo Formation, which consists of emergent, growth-position coral reefs and coral-bearing marine conglomerate. Elevations of both the reef facies and conglomerate facies on Oahu are usually 1 to $6 \mathrm{~m}$ above modern sea level, but shallow-marine or beach sediments are found as high as $13 \mathrm{~m}$ above sea level at two localities (Mokapu Point and Kahe Point). Oahu has probably experienced minor uplift due to lithospheric flexure from subsidence of the "Big Island" of Hawaii (Muhs and Szabo, 1994). Over the timescale considered here, however, Oahu can be considered to be relatively stable. An earlier study (Szabo et al., 1994) reported acceptable 
U-series ages of corals from the Waimanalo Formation that range from $130,000 \pm 2500$ to $110,500 \pm 3800$ yr B.P., with many ages between 129,000 and 118,000 yr B.P. (Fig. 2b). New, higher precision ages of different coral samples from the same localities on Oahu show a somewhat more restricted range of acceptable ages, from $127,500 \pm 800$ to $115,800 \pm 600 \mathrm{yr}$ B.P. (Muhs et al., 2002).

On the mainland coast and islands of Western Australia (Fig. 1c), emergent reefs and marine deposits, $2-4 \mathrm{~m}$ above sea level, are widespread, and the degree of coral preservation is generally high. Acceptable U-series ages of corals (Fig. 2c) range from $128,900 \pm 600$ to $116,100 \pm 300 \mathrm{yr}$ B.P. from mainland localities and Rottnest Island (Stirling et al., 1995, 1998). Stirling et al. $(1995,1998)$ emphasize that the main period of last interglacial coral growth was a more restricted interval from $\sim 128,000$ to 121,000 yr B.P. On the Abrolhos Islands, Zhu et al. (1993) interpret U-series data from corals to indicate that the last interglacial had a sea level above present from $\sim 133,000$ to 116,000 yr B.P., but by the criteria used here, only a single sample, with an age of $124,000 \pm 2000 \mathrm{yr}$ B.P., is acceptable.

Stable coastlines indicate that sea level during the last interglaciation was likely at an elevation near, or higher than, present by around $128,000 \mathrm{yr}$ B.P. and was probably still as high as or higher than present at least as late as $\sim 116,000 \mathrm{yr}$ B.P. The acceptable ranges of ages for corals from Hawaii (new analyses of Muhs et al., 2002) and Australia are not significantly different, and the range from the Bahamas is only slightly smaller than the other two localities. Thus, observations from several coastlines suggest that the last-interglacial high sea stand, with a global ice volume lower than present, probably had a duration of as much as $12,000 \mathrm{yr}$. A sea level higher than present from $\sim 128,000$ to $\sim 116,000$ yr B.P. has at least three important implications. One is that sea level rose to a relatively high level (i.e., as high or higher than present) more quickly after (or even slightly before) the Northern Hemisphere summer insolation peak at $\sim 127,000$ than at the end of the last glacial period. Northern Hemisphere summer insolation peaked at $\sim 11,000$ yr B.P. at the close of the last glacial period, yet sea level did not reach near-present elevations until about $7000-5000$ yr B.P. (see compilation in Fig. 3 of Lambeck and Chappell, 2001). A second implication of the coral record is that the last interglacial period of lower than present glacier ice volume is longer than the duration suggested by the foraminiferal oxygen isotope record in deep-sea sediments, perhaps by several thousand years. Finally, the SPECMAP oxygen isotope record indicates a major ice-growth event between $\sim 118,000$ and 112,000 yr B.P. (Martinson et al., 1987). By one estimate, oxygen isotope values indicate the amount of ice growth at this time to be on the order of $25 \times 10^{6} \mathrm{~km}^{3}$ (Mix, 1992), roughly equivalent to a sea level fall of 50-70 m. Nevertheless, emergent corals on stable coastlines in Australia, the Bahamas, Hawaii, and Bermuda have ages of 119,000-115,000 yr B.P. that suggest sea level was still relatively high well into what the SPECMAP chronology would consider to be a period of ice growth.

\section{ACKNOWLEDGMENTS}

Thanks go to George Kukla for inviting me to write this short review. My work on the last interglacial period was supported by the Earth Surface Dynamics Program of the U.S. Geological Survey as part of the LITE (Last Interglacial: Timing and Environment) Project. I thank Ike Winograd, George Kukla, and two anonymous referees for constructive comments on an earlier draft of the paper.

\section{REFERENCES}

Berger, A., and Loutre, M. F. (1991). Insolation values for the climate of the last 10 million years. Quaternary Science Reviews 10, 297-317.

Chen, J. H., Edwards, R. L., and Wasserburg, G. J. (1986). ${ }^{238} \mathrm{U}$, ${ }^{234} \mathrm{U}$, and ${ }^{232} \mathrm{Th}$ in seawater. Earth and Planetary Science Letters 80, 241-251.

Chen, J. H., Curran, H. A., White, B., and Wasserburg, G. J. (1991). Precise chronology of the last interglacial period: ${ }^{234} \mathrm{U}^{230} \mathrm{Th}$ data from fossil coral reefs in the Bahamas. Geological Society of America Bulletin 103, 82-97.

Edwards, R. L., Cheng, H., Murrell, M. T., and Goldstein, S. J. (1997). Protactinium-231 dating of carbonates by thermal ionization mass spectrometry: implications for Quaternary Climate Change. Science 276, 782-786.

Fruijtier, C., Elliott, T., and Schlager, W. (2000). Mass-spectrometric ${ }^{234} \mathrm{U}_{-}{ }^{230} \mathrm{Th}$ ages from the Key Largo Formation, Florida Keys, United States: Constraints on diagenetic age disturbance. Geological Society of America Bulletin 112, 267-277.

Gallup, C. D., Edwards, R. L., and Johnson, R. G. (1994). The timing of high sea levels over the past 200,000 years. Science 263, 796-800.

Kennett, J. P. (1995). Latest Quaternary benthic oxygen and carbon isotope stratigraphy: Hole 893A, Santa Barbara Basin, California. In "Proceedings of the Ocean Drilling Program, Scientific Results" Vol. 146, Part 2 (J. P. Kennett, J. G. Baldauf, and M. Lyles, Eds.), pp. 3-18.

Kukla, G. (2000). The last interglacial. Science 287, 987-988.

Lambeck, K., and Chappell, J. (2001). Sea level change through the last glacial cycle. Science 292, 679-686.

Martin, L., Suguio, K., and Flexor, J.-M. (1988). Hauts niveaux marins Pleistocenes du littoral Bresilien. Palaeogeography, Palaeoclimatology, Palaeoecology 68, 231-239.

Martinson, D. G., Pisias, N. G., Hays, J. D., Imbrie, J., Moore, T. C., Jr., and Shackleton, N. J. (1987). Age dating and the orbital theory of the ice ages: Development of a high-resolution 0 to 300,000-year chronostratigraphy. Quaternary Research 27, 1-29.

Mix, A. C. (1992). The marine oxygen isotope record; constraints on timing and extent of ice-growth events (120-65 ka). Geological Society of America Special Paper 270, 19-30.

Muhs, D. R., and Szabo, B. J. (1994). New uranium-series ages of the Waimanalo Limestone, Oahu, Hawaii: Implications for sea level during the last interglacial period. Marine Geology 118, 315-326.

Muhs, D. R., Simmons, K. R., and Steinke, B. (2002). Timing and warmth of the last interglacial period: New U-series evidence from Hawaii and Bermuda and a new fossil compilation for North America. Quaternary Science Reviews, in press.

Stirling, C. H., Esat, T. M., McCulloch, M. T., and Lambeck, K. (1995). Highprecision U-series dating of corals from Western Australia and implications for the timing and duration of the last interglacial. Earth and Planetary Science Letters 135, 115-130.

Stirling, C. H., Esat, T. M., Lambeck, K., and McCulloch, M. T. (1998). Timing and duration of the last interglacial; evidence for a restricted interval 
of widespread coral reef growth. Earth and Planetary Science Letters 160, $745-762$.

Stirling, C. H., Esat, T. M., Lambeck, K., McCulloch, M. T., Blake, S. G., Lee, D. C., and Halliday, A. N. (2001). Orbital forcing of the marine isotope stage 9 interglacial. Science 291, 290-293.

Szabo, B. J., Ward, W. C., Weidie, A. E., and Brady, M. J. (1978). Age and magnitude of the late Pleistocene sea-level rise on the eastern Yucatan Peninsula. Geology 6, 713-715.
Szabo, B. J., Ludwig, K. R., Muhs, D. R., and Simmons, K. R. (1994). Thorium230 ages of corals and duration of the last interglacial sea-level high stand on Oahu, Hawaii. Science 266, 93-96.

Zhu, Z. R., Wyrwoll, K. H., Collins, L. B., Chen, J. H., Wasserburg, G. J., and Eisenhauer, A. (1993). High-precision U-series dating of Last Interglacial events by mass spectrometry; Houtman Abrolhos Islands, Western Australia. Earth and Planetary Science Letters 118, 281293. 